\title{
Perineal Hygienic Practices in Patients of Himalayan Foothills - A Descriptive Study
}

\author{
Shashi Prateek ${ }^{1}$, Ankita Yadav², Latika Chawla ${ }^{3}$, Deepti Chaudhary ${ }^{4}$, \\ Neetu Kochhar ${ }^{5}$, Shailja Sharma ${ }^{6}$, Rakhi Gaur7, Nitika Grover ${ }^{8}$ \\ 1, 2, 3, 4, 5, 6, 8 Department of Obstetrics and Gynecology, AIIMS Rishikesh, Dehradun, Uttarakhand, India. ${ }^{7}$ Akal \\ College of Nursing, Eternal University, Baru Sahib (HP).
}

\section{ABSTRACT}

\section{BACKGROUND}

It has been said that health is wealth and when it comes to reproductive health of a women it has a significant value indeed. There is lot of loops and holes in perineal hygiene practices due to incomplete knowledge and various myth that is transferred from generation to generation in a family. The aim of the study was to study the perineal hygiene practices in women of Himalayan foothills.

\section{METHODS}

This is an observational study performed between March 2019 to February 2020 at AIIMS Rishikesh. Data was extracted from OPD records of patients which included details on perineal hygiene, routinely asked in one of the three units in department of obstetrics and gynaecology at AIIMS Rishikesh.

\section{RESULTS}

Total of 2400 women participated in the study. The mean age of subjects was $32 \pm$ 6.9(Range 12 - 80 years). Maximum patients were married (92\%), mostly Hindus ( $48 \%$ ) belonging to upper lower class (37.5\%) according to modified Kuppuswamy socioeconomic scale. In this study we studied the routine perineal cleaning practices, Attention is being drawn to the fact that only $15 \%$ of the subjects cleaned the genital area with water after urination, $5 \%$ while changing pads during menstruation, only $1.5 \%$ washed the genitalia immediately after sexual intercourse In present study the commonest method removal of perineal hair was shaving (38.4 $\%)$. While analysing menstrual hygiene, in present study, $42.5 \%$ of study population was using sanitary pads from market and $35 \%$ used homemade cloth pads. Ninety eight point seven percent of women avoided sexual intercourse during menstruation in present study.

\section{CONCLUSIONS}

Female genital hygiene is a vital topic. Awareness should be increased regarding maintenance of hygienic practices through health education programmes. More studies need to be performed in order to provide directions for proper female genital hygiene, as well as guidelines.

\section{KEY WORDS}

Perineal Hygiene, Pubic Hair Grooming, Menstrual Hygiene, Perineal Itching, Perineal Rashes, Long Mirror for Self Examination.
Corresponding Author:

Dr. Ankita Yadav,

Senior Resident,

Department of Obstetrics \& Gynaecology, AIIMS Rishikesh, Uttarakhand, India.

E-mail: ankitayadav28101992@gmail.com

DOI: $10.14260 / j e m d s / 2021 / 722$

How to Cite This Article:

Prateek S, Yadav A, Chawla L, et al. Perineal hygienic practices in patients of himalayan foothills - a descriptive study. $J$ Evolution Med Dent Sci 2021;10(41):35623565, DOI: 10.14260/jemds/2021/722

Submission11-12-2020,

Peer Review 23-09-2021,

Acceptance 01-10-2021,

Published 11-10-2021.

Copyright (c) 2021 Shashi Prateek et al. This is an open access article distributed under Creative Commons Attribution License [Attribution 4.0 International (CC BY 4.0)] 


\section{BACKGROUND}

"It has been said that Health is wealth and when it comes to the reproductive health of a woman it has a significant value indeed." Perineal hygiene is one of the least concern areas for most of the women. While on one hand, women are more conscious about their looks, on the other hand, they are not paying enough attention to cleanliness of genital organs. This is because these body parts are hidden beauties and need internal strength of superior level consciousness for taking care of these important body parts. Carelessness towards grooming of pubic hair, use of unsterilized cloth instead of sterilised sanitary pads. Cleaning practices, after nature's call and sexual activity, are some examples which portray the picture of a women's reproductive health among rural as well as urban community. Despite common anatomical structure of reproductive organs of all women, attitude towards hygienic practices vary among countries, cultures, societies and individuals. ${ }^{1}$

The term perineal hygiene is used for caring and maintaining the external genital and perianal area. A wide variety of friendly microorganisms are found in the female genital tract which are commonly known as commensal which play a significant role in maintenance of $\mathrm{pH}$ of perineum and are responsible for its health. Lack of awareness, misinformation and poor hygienic conditions may change the flora which may become pathogenic and cause various types of infections. ${ }^{2}$ In developing countries like India, 43 - $88 \%$ women are using cloth during menstruation. Many a times these may be unclean and may lead to perineal rash and infections. Such kind of practices are usually passed from one generation to another as a part of their cultural practices. ${ }^{3}$ Women's genital anatomy is also a contributing factor for making them more prone to infections than man. ${ }^{1}$ Reproductive tract infections (RTIs) including sexually transmitted infections (STIs) can be prevented if women are educated regarding proper perineal hygiene. ${ }^{4}$ Unsupported family, illiteracy, lack of resources and unawareness are some of significant contributing factors responsible for poor perineal hygiene practices among women. ${ }^{2}$

Present study was carried out to identify and explore the perineal hygiene practices of women along with details on type of sanitary napkins used, hygiene during menstruation and sexual activity so that appropriate measures can be planned to educate women and promote reproductive health.

\section{METHODS}

This is an observational study approved by institutional committee and was performed between March 2019 to February 2020. Since the study was a observational study between March 2019 and Feb 2020, all the patient attending opd between this time duration were included in the study, there was no predefined sample size.

\section{Ethical Statement}

Ethical clearance for the study was taken from AIIMS RISHIKESH and the study was conducted in the department of obstetrics and gynaecology, the data was extracted from the OPD records of the patients

\section{Data Collection Procedure}

Data was extracted from OPD records of patients which included details on perineal hygiene, routinely asked in one of the three units in department of obstetrics and gynaecology at AIIMS Rishikesh.

\section{Analytical Approach}

The data collected were encoded into Microsoft Excel sheet and analysed using SPSS version 21. Data was analysed using appropriate statistical tests like frequency and percentage for demographic characteristics and perineal hygiene practices.

\section{RESULTS}

During the study period, data of Twenty four hundred females was recorded. Demographic profile of subjects is shown in Table 1.

\begin{tabular}{|c|c|c|c|}
\hline \multirow{2}{*}{\multicolumn{2}{|c|}{$\begin{array}{l}\text { Age in Years (Range } 12 \text { - } 80 \text { years) } \\
\text { Variable }\end{array}$}} & \multicolumn{2}{|c|}{$32 \pm 6.9$} \\
\hline & & $\%$ & No. \\
\hline \multirow{3}{*}{ Religion } & Hindu & 48.5 & 1164 \\
\hline & Muslim & 36.5 & 876 \\
\hline & Other & 15 & 360 \\
\hline \multirow{6}{*}{ Education } & Illiterate & 3.5 & 84 \\
\hline & Just literate & 24 & 576 \\
\hline & Primary level & 36 & 864 \\
\hline & Secondary level & 16 & 384 \\
\hline & Senior secondary level & 10 & 240 \\
\hline & Graduate and above & 10.5 & 252 \\
\hline \multirow{3}{*}{ Marital status } & Unmarried & 4.2 & 101 \\
\hline & Married & 92 & 2208 \\
\hline & Widow / Divorce & 3.8 & 91 \\
\hline \multirow{5}{*}{$\begin{array}{c}\text { Socioeconomic status } \\
\text { (Modified Kuppuswamy scale) }\end{array}$} & Lower class $(<5)$ & 30.5 & 732 \\
\hline & Upper lower (5 - 10) & 37.5 & 900 \\
\hline & Lower middle $(11-15)$ & 17.5 & 420 \\
\hline & Upper middle $(16-25)$ & 9.5 & 228 \\
\hline & Upper class $(26-29)$ & 5 & 120 \\
\hline \multirow{4}{*}{ Body mass index } & Underweight $(<18.5)$ & 11 & 264 \\
\hline & Normal (18.5-25) & 52 & 1248 \\
\hline & Overweight (25-30) & 31.5 & 756 \\
\hline & Obese $(>30)$ & 5.5 & 132 \\
\hline \multicolumn{4}{|c|}{ Table 1 Demographic Profile of Study Subject } \\
\hline
\end{tabular}

The mean age of subjects was $32 \pm 6.9$ (Range $12-80$ years). Maximum patients were married (92 \%), mostly Hindus (48\%) belonging to upper lower class (37.5\%) according to modified Kuppuswamy socioeconomic scale.

The majority of women took bath daily and washed perineum during bath with soap and water (99\%). More than $99 \%$ women were washing perineum after defecation $(99.87$ $\%)$. There were 5 women who used water in routine but in case of emergency when out of home, used soil lump to clean after defecation. Only $15 \%$ washed perineum after micturition, cleaning material used by maximum women was water $(10 \%)$, tissue $(2.5 \%)$ and other over the counter products $(2.5 \%)$. It was very interesting to find that only $5 \%$ of women who washed perineum after micturition had history of drying the perineum with tissue paper (65\%) or towelette (35\%) and as far as use of fresh towelette is concerned majority of women washed it daily $(81.06 \%)$.

In present study $97.7 \%$ women reported removing pubic hair at some point of time, the frequency of removal of perineal hair was every 15 days in $5.25 \%$, once a month in 
$53.04 \%$, more than 2 months is $15.33 \%$ and whenever feasible or required in $24.08 \%$. The method used for hair removal was primarily a razor blade (28.4\%), but other methods, such as trimming with electric trimmer or scissors, cream, and waxing was also reported.

\begin{tabular}{|c|c|c|c|}
\hline Variables & & $\%$ & No. \\
\hline \multirow{4}{*}{ Perineal cleaning practices } & Cleaning during bath & 100 & 2400 \\
\hline & Cleaning after urination & 15 & 360 \\
\hline & Cleaning after defecation & 99.87 & 2397 \\
\hline & $\begin{array}{l}\text { Cleaning while changing pads during } \\
\text { periods }\end{array}$ & 5 & 120 \\
\hline \multirow{2}{*}{$\begin{array}{l}\text { Cleaning material used for } \\
\text { cleaning the perineum } \\
\text { during bath }\end{array}$} & Water only & 1 & 24 \\
\hline & Soap and water & 99 & 2376 \\
\hline \multirow{4}{*}{$\begin{array}{l}\text { Cleaning material used for } \\
\text { cleaning perineum after } \\
\text { urination }\end{array}$} & Nil: & 85 & 2040 \\
\hline & Water & 10 & 240 \\
\hline & Tissue & 2.5 & 60 \\
\hline & $\begin{array}{l}\text { Traditional antiseptics (chlorhexidine / } \\
\text { soap, iodine solution, chloroxylenol) }\end{array}$ & 2.5 & 60 \\
\hline \multirow{4}{*}{ Underwear material } & Cotton & 37.5 & 900 \\
\hline & Synthetic & 21 & 504 \\
\hline & Other (silk, Satan) & 10 & 240 \\
\hline & Not using underwear & 31.5 & 754 \\
\hline \multirow{2}{*}{$\begin{array}{c}\text { Using underwear at sleeping } \\
\text { time }\end{array}$} & No & 76 & 1824 \\
\hline & Yes & 24 & 576 \\
\hline \multirow{2}{*}{$\begin{array}{l}\text { Habit of drying perineum } \\
\text { after urination and } \\
\text { defecation }\end{array}$} & No $(95 \%)$ & 95 & 2280 \\
\hline & $\begin{array}{lc}\text { Yes }(5 \%) & \text { Tissue paper } \\
\text { Towelette }\end{array}$ & $\begin{array}{l}65 \\
35\end{array}$ & $\begin{array}{l}78 \\
42\end{array}$ \\
\hline \multirow{5}{*}{$\begin{array}{l}\text { Frequency of use of fresh } \\
\text { towelette with urination }\end{array}$} & Every time after use & 2.3 & 1 \\
\hline & Daily & 81.06 & 34 \\
\hline & Less than weekly & 9.5 & 4 \\
\hline & Weekly & 7.14 & 3 \\
\hline & More than a week & Nil & Nil \\
\hline \multirow{5}{*}{$\begin{array}{l}\text { Frequency of perineal hair } \\
\text { removal }\end{array}$} & Never & 2.3 & 55 \\
\hline & Every 15 days & 5.25 & 126 \\
\hline & Once a month & 53.04 & 1273 \\
\hline & More than 2 months & 15.33 & 368 \\
\hline & Whenever required / feasible & 24.08 & 578 \\
\hline \multirow{6}{*}{$\begin{array}{l}\text { Method of removal of } \\
\text { perineal hair }\end{array}$} & Razor blade & 28.4 & 682 \\
\hline & Trim (electric hair trimmer) & 13.46 & 323 \\
\hline & Trim (scissor) & 12.7 & 305 \\
\hline & Cream & 13.15 & 315 \\
\hline & Wax & 12.29 & 295 \\
\hline & Vary time to time) & 20 & 480 \\
\hline l & es of Routine Perineal Clea & & \\
\hline
\end{tabular}

\begin{tabular}{|cccc|}
\hline Variable & Pad & \% & No \\
& Cloth & 42.5 & 1020 \\
Menstrual blood & Tampons & 35.5 & 852 \\
absorbent / collector & Menstrual cup & 4.46 & 107 \\
& Not required (before menarche, & 0.04 & 1 \\
& amenorrhoea or post - menopausal) & 17.5 & 420 \\
Sexual intercourse during & No & 98.7 & 2369 \\
menstruation & Yes & 1.3 & 31 \\
Practices in relation & Urination immediately before intercourse & 51.5 & 1236 \\
intercourse & Urination immediately after intercourse & 13.5 & 324 \\
& Never corelated urination with intercourse & 35 & 840 \\
Cleaning perineum after & Washing & 1.5 & 36 \\
intercourse & Wiping & 98 & 2352 \\
& Nil & 0.5 & 12 \\
& No & 83.04 & 1992 \\
Lubrication during & Medicated cream & 6.4 & 154 \\
intercourse & Jelly & 10.4 & 250 \\
& Yes & 0.16 & 4 \\
\hline Table 3. Variables for Perineal Hygiene during Menstruation \& Sexual \\
& Activity & & \\
\hline
\end{tabular}

Out of 2400 women 42.5 were using sanitary napkins from market as absorbent material during their menstrual cycle, while $35.5 \%$ were using cloth, $4.46 \%$ used tampons whereas one foreigner (German women) used menstrual cups. It was found that only $5 \%$ of women washed perineum while changing of pad. It was seen that $98.7 \%$ of women avoided sexual intercourse during menstruation.

On inquiring about practices of urination in relation to intercourse, it was found that $51.5 \%$ women practiced urination before sexual intercourse while only $13.5 \%$ immediately after sexual intercourse and $35 \%$ did not corelate urination with sexual intercourse. Ninety eight percent women practised cleaning of perineum by wiping with cloth after intercourse whereas $1.5 \%$ had habit of washing the perineum with water. However, it was strange to find that $0.5 \%$ did not cleaned perineum at all after intercourse.

\begin{tabular}{|cccc|}
\hline Variables & & \% & No. \\
Past History of Perineal & Yes & 58.6 & 1406 \\
rashes & No & 41.4 & 994 \\
Past history of Itching in & Yes & 65.58 & 1574 \\
perineal region & No & 34.42 & 826 \\
How did they came to know & During routine examination by a doctor & 51 & 1224 \\
about rash in perineal region & Seen by partner & 40.5 & 972 \\
Long mirror available in & Self - examination using mirror & 8.5 & 204 \\
privacy & Yes & 9.5 & 228 \\
\hline Table 4. Variables in Relation to Perineal Itching / Rashes & \\
\hline
\end{tabular}

On enquiring about past history $58.61 \%$ women gave history of perineal rash and $65.58 \%$ gave history of itching in perineal region at some point of time in past. The diagnosis of perineal rash in majority of women (51\%) was made during routine examination by a doctor or paramedic, some women came to know when they developed itching and was seen by partner or she examined in mirror. It was very interesting to find that only $9.5 \%$ of females had a long mirror (example in bathroom, bedroom, in assigned area) for self - examination.

\section{DISCUSSION}

This study examined the perineal hygiene practices among women of Himalayan foothills. This study helps to add to the limited data available on this subject. While there are some studies available on the perineal hygiene practices but majority of these are limited to western world. Strength of present study includes the large sample size and inclusion of extensive array of behaviours in the different age group.

Regarding perineal hygiene, attention is being drawn to the fact that only $15 \%$ of the subjects cleaned the genital area with water after urination, $5 \%$ while changing pads during menstruation, only $1.5 \%$ washed the genitalia immediately after sexual intercourse. It is known that accumulation of residues of urine, sperm, faeces, menstrual blood and scrapes of paper promotes irritation and itching, so that they may predispose to the formation of cracks and cause perineal infection. These hygienic practices are almost similar in all strata of education. In a similar descriptive study by Ruiz et al on daily genital cares of female gynaecologists, only $25.9 \%$ practiced washing of genitalia with running water after urination and $52.7 \%$ sanitized themselves after sexual relation. ${ }^{5}$ Similar results were seen in a study by Giraldo et al in their survey on 341 university students of a large Brazilian university. ${ }^{6}$

Pubic hair grooming practices are currently considered as social norm however, very little data on the topic exists. There are many reasons for removal of pubic hair like hygiene and cosmetic however the main reason for perineal hair grooming were for comfort and preventing odour. ${ }^{7}$ In present study the commonest method was shaving (38.4\%). Similarly, in a study by Rouzi et al the most common single method of removal of pubic hair was razor blade (33.5\%). ${ }^{8}$ It was observed in present study that $77 \%$ of the population removed pubic hair monthly similar to a study by AlGhamdi $\mathrm{KM}$ et al in which removal of pubic hair was practiced once in 
40 days. $^{9}$ The results of the study are consistent with previous studies in different study population.

While analysing menstrual hygiene, in present study, 42.5 $\%$ of study population was using sanitary pads from market and $35 \%$ used homemade cloth pads. Women who used cloth for menstrual protection, majority discarded the cloth after every use however very few reused the cloth after washing. Similarly habit of reusing the cloth was found in a study done by Santra S. on reproductive age women of slum area of Kolkata, west Bengal, India. ${ }^{10}$ It was found that only $5 \%$ of women were doing perineal washing while changing of pad. Privacy for washing, changing of pads or cleaning purpose is something very important for proper menstrual hygiene but in it was seen that, lack of privacy was an important problem, both at home or at school / work place. The results of present study are consistent with previous reports in different study populations. Similar results were seen in a community based study on menstrual hygiene among adolescent girls in a study done by Jogdand K. ${ }^{11}$

Ninety eight point seven percent of women avoided sexual intercourse during menstruation in present study. Which match the results seen in a study by Mazokopakis E et al. According to the Old Testament (Provisions for clean and unclean of the Mosaic Law), a woman during menstruation or a man who has sexual relations with a menstruating woman are perceived as "unclean". When seven days pass after the first day of menstruation, the woman is regarded as "clean" and sexual contact is permitted.12 Modern medical science also discourages practice of sexual intercourse during menstruation as it has been reported that there are higher risk of infection and endometriosis to the female partner. Menstruation should not be treated as a dirty phenomenon and it should not be a hindrance to daily activities. Sanitary pads should be made available free or at affordable price and it should be easily accessible. Clean toilet, water and facilities to dispose sanitary pads should be made available at schools and at work place. Discussion about intimate hygiene should be a routine at home and at schools. This topic should not be considered a taboo. As a frontline health care worker, it's our duty to promote healthy perineal hygienic practices.

\section{CONCLUSIONS}

Female genital hygiene is a vital topic. Awareness should be increased regarding maintenance of hygienic practices through health education programmes. More studies need to be performed in order to provide directions for proper female genital hygiene, as well as guidelines.
Data sharing statement provided by the authors is available with the full text of this article at jemds.com.

Financial or other competing interests: None.

Disclosure forms provided by the authors are available with the full text of this article at jemds.com.

\section{REFERENCES}

[1] Patil PS, Rao AV. Study of reproductive hygiene among married women at urban field practice area, Dharwad. Int J Community Med Public Health 2018;5(10):4393-7.

[2] Attieh E, Maalouf S, Roumieh D, et al. Feminine hygiene practices among female patients and nurses in Lebanon. Reprod Health 2016;13(1):59.

[3] Pete PNM, Mabvouna Biguioh RM, Izacar AGB, et al. Genital hygiene behaviors and practices: a crosssectional descriptive study among antenatal care attendees. J Public Health Afr 2019;10(1):746.

[4] Shah SK, Shrestha S, Maharjan PL, et al. Knowledge and practice of genital health and hygiene among adolescent girls of Lalitpur Metropolitan City, Nepal. American Journal of Public Health Research 2019;7(4):151-6.

[5] Ruiz C, Giraldo PC, Sanches JM, et al. Daily genital cares of female gynecologists: a descriptive study. Rev Assoc Med Bras (1992). 2019;65(2):171-6.

[6] Giraldo PC, Polo RC, Amaral RLG, et al. Hábitose costumes de mulheres universitárias quanto ao uso de roupas íntimas, adornos genitais, depilação e práticas sexuais. Rev Bras Ginecol Obstet 2013;35(9):401-6.

[7] Muallaaziz D, Yayci E, Ataçağ T, et al. Pubic hair removal practices in Muslim women. Basic Clin Sci 2014;3:39-44.

[8] Rouzi AA, Berg RC, Turkistani J, et al. Practices and complications of pubic hair removal among Saudi women. BMC Women's Health 2018;18(1):172.

[9] AlGhamdi KM, AlHomoudi FA, Khurram H. Skin care: historical and contemporary views. Saudi Pharm J 2014;22(3):171-8.

[10] Santra S. Assessment of knowledge regarding menstruation and practices related to maintenance of menstrual hygiene among the women of reproductive age group in a slum of Kolkata, West Bengal, India. Int J Community Med Public Health 2017;4(3):708-12.

[11] Jogdand K, Yerpude P. A community based study on menstrual hygiene among adolescent girls. Indian Journal of Maternal and Child Health 2011;13(3).

[12] Mazokopakis E, Samonis G. Is vaginal sexual intercourse permitted during menstruation? A biblical (Christian) and medical approach. Maedica (Buchar) 2018;13(3):183-8. 